Article

\title{
Examining the Ritual Landscape of Bronze Age Crete through the Lens of Archaeobotany
}

\author{
Carly Henkel * and Evi Margaritis
}

Citation: Henkel, Carly, and Evi Margaritis. 2022. Examining the Ritual Landscape of Bronze Age Crete through the Lens of Archaeobotany. Religions 13: 81. https://doi.org/10.3390/rel13010081

Academic Editor: Martin Hoondert

Received: 30 September 2021

Accepted: 12 January 2022

Published: 17 January 2022

Publisher's Note: MDPI stays neutral with regard to jurisdictional claims in published maps and institutional affiliations.

Copyright: () 2022 by the authors. Licensee MDPI, Basel, Switzerland. This article is an open access article distributed under the terms and conditions of the Creative Commons Attribution (CC BY) license (https:/ / creativecommons.org/licenses/by/ $4.0 /)$.

\author{
Science and Technology in Archaeology and Culture Research Center (STARC), The Cyprus Institute, \\ Nicosia 2121, Cyprus; e.margaritis@cyi.ac.cy \\ * Correspondence: c.henkel@cyi.ac.cy
}

\begin{abstract}
This paper investigates plant remains at three ritual sites from Bronze Age Crete: Kophinas, Knossos Anetaki and Petras. To date, ritual contexts on the island have been little investigated from an archaeobotanical standpoint. Analysis of the plant material from these three sites provides new data for the use of plants in ritual activities in both mortuary and non-mortuary contexts. The results are discussed from a semiotic and emotive perspective, allowing for a better grasp of the potential plant-related rituals responsible for the creation of these archaeobotanical assemblages, including instances of plant sacrifice, symbolic plant sacrifice and the ritual deposition of intentionally charred plant remains. These findings are then integrated with previously published data from Crete and Mainland Greece in order to provide a broader picture of ritual plant use for the island, as well as the Aegean region. The recurrent evidence for the intentional charring of plant material and the presence of taxa commonly associated with everyday contexts indicates that fire was an important aspect of ritual activities involving plants and that the same suite of plant remains was engaged in the social activities of both the domestic and ritual spheres.
\end{abstract}

Keywords: archaeobotany; ritual; Bronze Age; Crete; plant sacrifice; funerary; Minoan

\section{Introduction}

In discussing prehistoric religions in the Aegean region, Renfrew (2011) notes that during this time period ritual contexts of the region are not as conspicuous as the monumental 'temple' structures of the Near East or of the later Classical and Archaic periods. His observation could explain why far more archaeobotanical studies exist for first-millennium ritual contexts in the Aegean (for a review, see Megaloudi 2005; Sarpaki 2019) than for prehistoric ones. To a large extent, however, Bronze Age ritual activity on Crete played out at very prominent sites within the landscape, such as peak sanctuaries, ritual caves and urban shrines. Yet, despite long-standing awareness of such sites, ritual contexts on Crete have received very little archaeobotanical attention until recently (for a review of the evidence from Crete, see Livarda and Kotzamani 2013). This past neglect did not stem from a disinterest in studying such contexts but rather from a prior lack of sampling on the part of excavators and a previous focus on questions concerning diet, subsistence, environment and economy on the part of archaeobotanists (Margaritis 2017).

As the discipline of archaeobotany has adopted new analytical methods and theoretical frameworks, however, investigations into human-plant interactions have gradually expanded beyond traditional lines of inquiry to include topics such as ritual and religion (Livarda and Madgwick 2018). The catalyst for this growth pertains primarily to the rise of concepts and techniques that allowed for the examination and conceptualization of the more dynamic ways in which plants served human communities. Advances in scientific methods, such as residue analysis, offered a means of exploring alternative uses of plants for which there was previously very little evidence, such as the production of perfumes, while the development of ideas related to social archaeology, material agency and the 
archaeology of the senses promoted researchers to consider plants as more than mere calorific necessities. The combined effect resulted in studies that began to address the more semiotic and emotive uses of plants, including their sensory potential (e.g., Hamilakis 2014; Bradley 2015; Rudolph 2017; Picornell-Gelabert et al. 2018), their social impact (e.g., Palmer and Van der Veen 2002; Hamilakis and Sherratt 2012) and their involvement in practices connected to belief systems (e.g., Megaloudi 2005; Margaritis 2014a; Fairbairn et al. 2019).

In terms of the religion practiced by the ancient civilization that lived on Crete during the Bronze Age (c. 3000-1000 BC), our understanding of related cult activities has largely been drawn from material culture and iconographic studies since written sources are lacking. The general conclusion is that the basis for their ritual practices started with funerary rites and evolved from there to include worship at liminal-type locations in the landscape, such as caves and mountain tops, and public spaces often associated with their palaces (Gesell 1985; Marinatos 1993; Younger and Rehak 2008; Lupack 2010). Based on the archaeological evidence, Minoan belief is thought to have been quite performative (Younger and Rehak 2008; Peatfield 2002; Peatfield and Morris 2012), centering around a female deity or deities and concerning notions of fertility, as well as seasonal and life cycles (Lupack 2010; Younger and Rehak 2008). Activities associated with the dead included grave side feasting and secondary manipulation of remains (Mee 2010), while events at liminal sites and urban shrines involved the offering of votives, likely in connection to both individual and communal concerns, such as healing (Peatfield 1990) and pastoral pursuits (Peatfield 1983; Lupack 2010).

Like Minoan religion itself, the archaeobotanical study of ritual plant remains on Crete began with funerary contexts. The first systematic work was conducted by Margaritis (2014a) in a study that examined plant remains recovered at a number of prehistoric mortuary sites on the island, as well as Mainland Greece. Subsequent archaeobotanical analysis of the Pre- and Protopalatial house tombs at Petras (Margaritis 2017) and the Late Geometric graves at Kavousi Vronda (Flint-Hamilton 2016) have since provided additional information about ritual plant remains from funerary contexts. Collectively, these publications demonstrate the intentional use of plants in mortuary practices on Crete from the third to first millennium BC.

Investigations into the use of plants at non-mortuary sites, however, are still absent. Doctoral research by one of the authors (Henkel) is currently attempting to rectify this situation by examining plant remains from a broader range of ritual site types dated to the island's Bronze Age period (Henkel 2021). This work focuses primarily on non-mortuary contexts in order to evaluate the role of plants within the wider ritual landscape at that time. The aim of this paper is to present new archaeobotanical results from the open-air sanctuary at Kophinas, the Fetish Shrine at Knossos Anetaki and the most recently studied funerary contexts at Petras (Figure 1). While the plant data from two of the sites will be individually published in forthcoming excavation volumes (Henkel and Margaritis forthcoming a; Henkel et al. forthcoming), the archaeobotanical evidence is being synthesized here with the intention of offering a more integrated understanding for the use of plants in Minoan ritual landscape. 


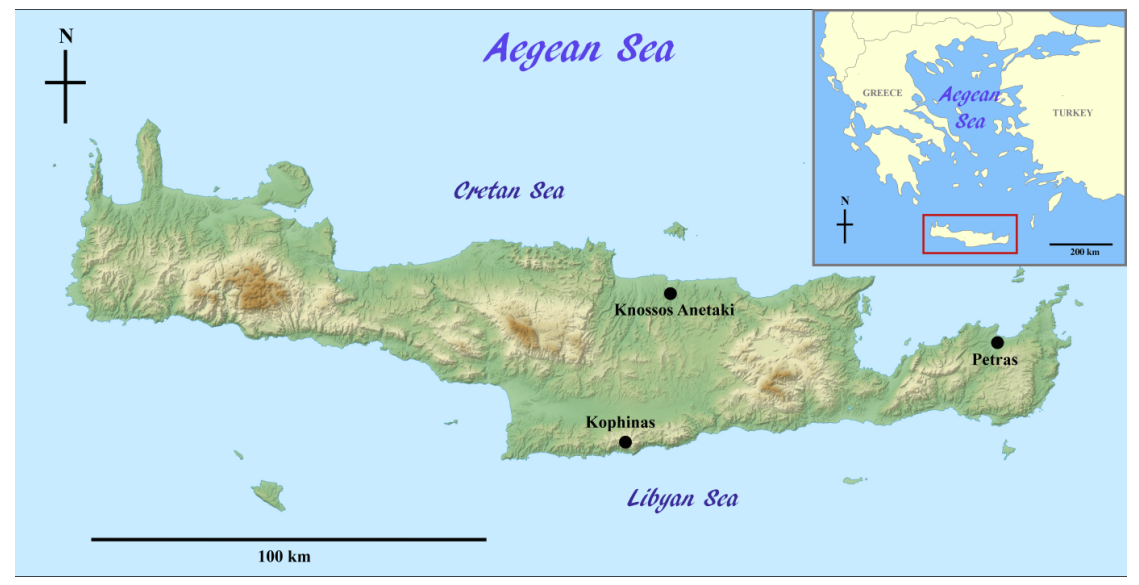

Figure 1. Map of Crete showing the three Bronze Age ritual sites (modified from: Crete_relief_mapfr.svg: Eric Gaba [Sting—fr:Sting] derivative work: Xfigpower [pssst]—Crete_relief_map-fr.svg, CC BY-SA 3.0, https: / commons.wikimedia.org/w / index.php?curid=11905589, public domain Wiki Commons, accessed on 30 September 2021).

\section{The Sites and Samples}

\subsection{Kophinas}

The site of Kophinas is located in North-Central Crete within the prefecture of Heraklion. It consists of an open-air sanctuary nestled $970 \mathrm{~m}$ above sea level below the highest peak of the Asterousia Mountains, also known as Kophinas. The sanctuary occupies a rectangular area (appr. $240 \mathrm{~m} \mathrm{sq.),} \mathrm{which} \mathrm{is} \mathrm{delineated} \mathrm{by} \mathrm{a} \mathrm{peribolos} \mathrm{wall} \mathrm{on} \mathrm{its} \mathrm{North,} \mathrm{East}$ and South-East sides and is bounded by natural mountain crag on its West and South-West sides (Figure 2a).

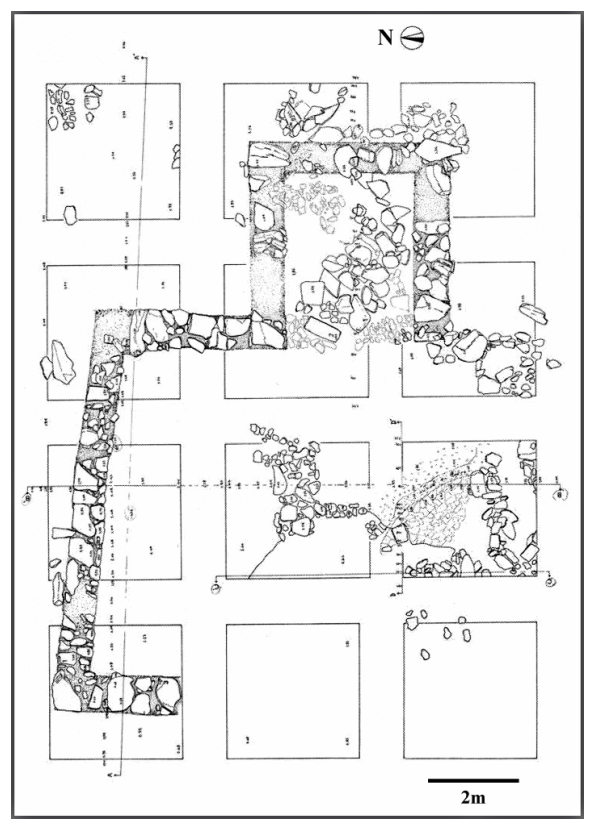

(a)

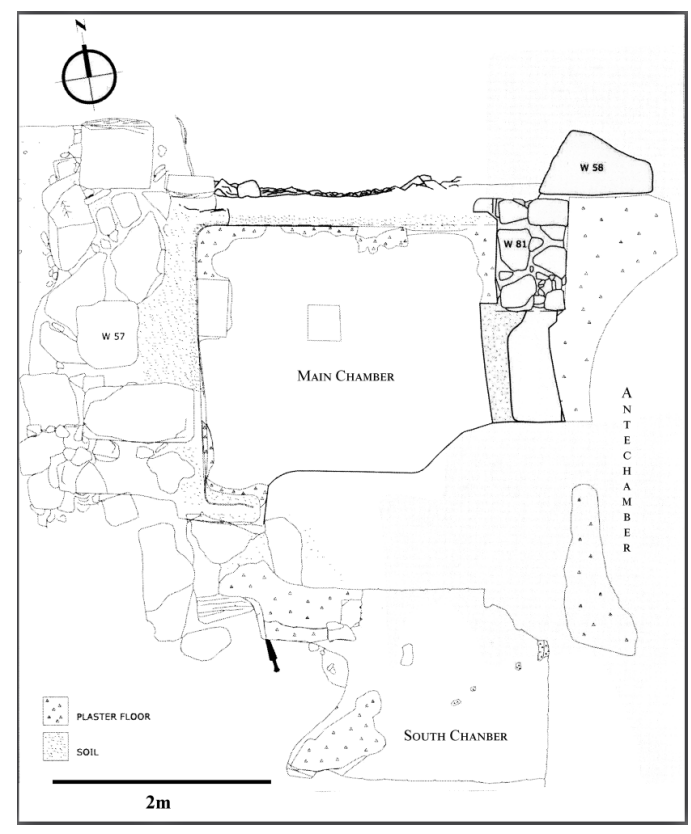

(b)

Figure 2. (a) Plan of the open-air sanctuary at Kophinas in South-Central Crete (image courtesy of the director of the 1990 Kophinas excavation, Dr. Alexandra Karetsou). (b) Plan of the Fetish Shrine uncovered by the excavations at Knossos Anetaki in North-Central Crete (image courtesy of the director of the Knossos Anetaki excavations, Dr. Athanasia Kanta).

The site was first discovered in 1959 by Nikolaos Platon after a series of clay figurines from the area were turned over to the local ephorate. Platon later excavated the site, 
together with the late Kostas Davaras, in 1961 (Platon and Davaras 1961; Alexiou 1963). Thirty years later, in 1990, Alexandra Karetsou and Giorgos Rethemiotakis conducted further work as part of rescue excavations in response to illegal looting at the sanctuary (Karetsou 2014). Together, the two excavation campaigns revealed that the natural rock barrier and a large, square recess in the East wall of the peribolos formed the focal points of ritual activity (Karetsou 2014, 2018). Platon's initial excavations noted the deliberate placement of numerous figurines within the crevices of the craggy rock, while the more recent excavations uncovered an impressive collection of votive-type finds, including a lead double ax, fragments of clay boat models, stone offering tables, various human and animal figurines; seal stones; bronze daggers; and a variety of precious beads, many of which were concentrated in front of and near to the niche in the peribolos (for a fuller description of the finds and site, see Karetsou 2014). Both excavations also discovered that the site's deeper stratigraphic level contained a significant ash layer, which likely represented the remains of sacrificial pyres (Alexiou 1963; Karetsou 2014). The 1990 excavations further revealed that a low wall touching a built platform in the center of the sanctuary enclosed much of this ashy layer. It was during this excavation that seven sediment samples were collected from both these pyre remains and a few other contexts.

The sanctuary's stratigraphy is somewhat complicated by its long period of use from the Neopalatial period (c. 1750-1450 BC) up to the Roman times. While upper levels produced mixed ceramic deposits, the deepest level yielded layers of homogenous Middle Minoan III (c. 1750-1700 BC) pottery-the site's main period of activity (Spiliotopoulou 2014). Stylistically, the pottery and figurines from the ash layer also belong to this period, though some Hellenistic ceramic admixture was present (personal communication, Karetsou and Spiliopoulou). The size of the Neopalatial pottery assemblage suggests that a large number of visitors/spectators traveled to this sacred location, while the character of the vessels, mainly cups and tripod cookpots, implies that food and drink consumption formed part of the activities that took place at the site (Karetsou 2014; Spiliotopoulou 2014).

\subsection{Knossos Anetaki}

Excavations at Knossos Anetaki have revealed evidence of continued ritual activity occurring at this location from the Protopalatial period (c. 1900-1750 BC) to the Roman era. The site consists of a private plot of land located $119 \mathrm{~m}$ above sea level in South-Central Crete, within the prefecture of Heraklion. It lays only c. $250 \mathrm{~m}$ to the West of the Minoan Palace at Knossos. The Anetaki plot first came under archaeological investigation in 2011, with excavations being directed by Athanasia Kanta. This investigation continued under the auspices of both the 23rd Ephorate of Antiquities and the Institute for Aegean Prehistory Study Center for East Crete (INSTAP-SCEC) up until 2016.

Part of the diachronic ritual activity at this site involved a small building known as the Fetish Shrine. This shrine comprises a square construction (c. $4.2 \times 4.2 \mathrm{~m}$ ) made up of three rooms: an Antechamber; a Main Chamber; and a South Chamber (Figure 2b). The Antechamber is a narrow front room (c. $1 \mathrm{~m}$ in width) that runs the entire length of the building from North to South and gives access to both the Main and South Chambers. Only a few patches of the plaster floor of this room were discovered in situ, since the rest of it was largely destroyed by later phases of use at the site. Likewise, the small South Chamber (c. $1.9 \times 2.3 \mathrm{~m}$ ) was also poorly preserved, though excavation of this room revealed a plastered bench that contained a foundation deposit consisting of a bronze griffin dagger. The Main Chamber formed the largest and best-preserved room within the shrine building (c. $2.3 \times 2.3$ ). It contained a central pillar-like altar and a small bench, built against the back wall, opposite the pillar. Three 'fetish idols' (pieces of stalagmite with anthropomorphic appearance) were discovered, placed in situ, on this bench, while the room's undisturbed floor deposit yielded several intact ceramic vessels of a cultic nature (for a fuller description of the Fetish Shrine and its finds, see Kanta forthcoming).

The pottery assemblage recovered from the Fetish Shrine dates its use to the end of the Monopalatial period (Late Minoan IIIB, c. 1350-1200 BC), and given the site's proximity 
to the palace, this shrine likely functioned as an urban place of ritual activity. A total of 78 sediment samples were collected from the shrine's three rooms for archaeobotanical analysis. These samples came from layers just above and on the floor. They were collected mostly in connection with the presence of charcoal and, due to the differential preservation of the three rooms, the majority were taken from the Main Chamber.

\subsection{Petras}

The Pre- and Protopalatial cemetery at Petras (Early Minoan I-Middle Minoan II, c. 3000-1750 BC) (Figure 3a) is situated on top of a hill in East Crete that lies on the outskirts of the modern-day city of Siteia within the prefecture of Lassithi. The hilltop sits at 54-60 $\mathrm{m}$ above sea level and commands a view of both the Siteia Bay to the North and a large valley to the South. The cemetery consists of square and rectangular house tombs, each featuring a unique architectural plan of several rooms. These tombs were mostly used for the purpose of secondary burials, likely by the inhabitants of the nearby palace and settlement, which are located on an adjacent hill just to the West.

(a)
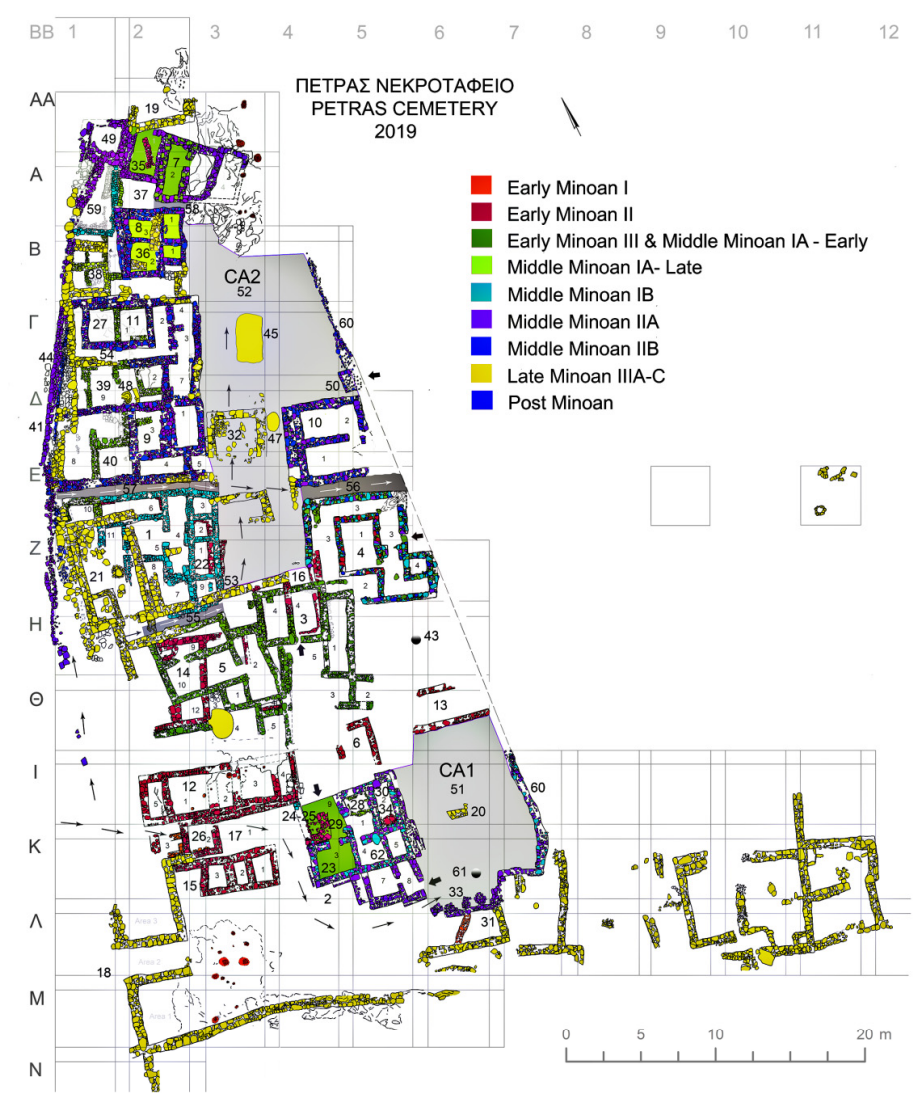

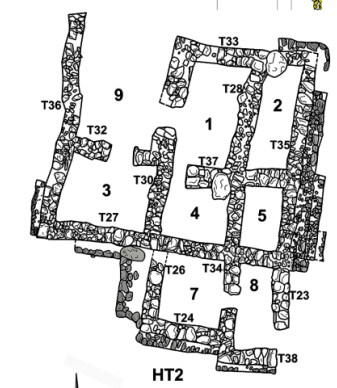

(b)

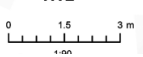

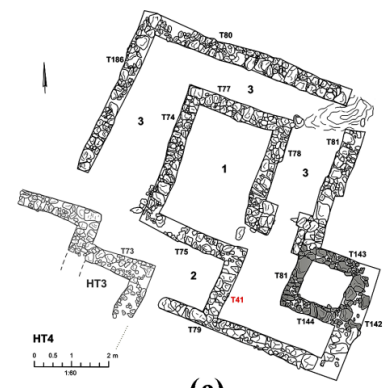

(c)

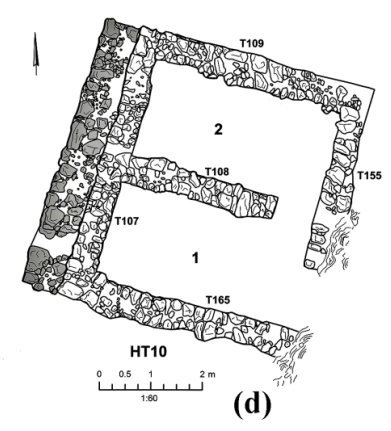

(d)

Figure 3. The site of Petras. (a) Plan of the cemetery showing the 24 house tombs, 9 burial structures and 2 open-air areas excavated to date. (b) Detailed plan of House Tomb 2. (c) Detailed plan of House Tomb 4. (d) Detailed plan of House Tomb 10 (all images courtesy of the director of the Petras excavations, Dr. Metaxia Tsipopoulou, and the Petras Excavation Archives). 
The burial ground was first discovered by the Petras excavation team during their earlier work at the sites on the Western hill in the late 1990s and early 2000s. Systematic excavation of the house tombs first occurred between 2004 and 2006 and has continued from 2009 until the present under the direction of Metaxia Tsipopoulou. To date, 24 house tombs have been excavated, as well as nine burial structures and two open-air areas that were reserved for ritual ceremonies connected with the funerary practices at this site. All of the excavated sediment from this cemetery has been kept for analysis.

For the purposes of this paper, only House Tombs 2, 4 and 10-the focus of the most recent archaeobotanical study of the site (Henkel et al. forthcoming)—will be presented in detail (for the previous archaeobotanical study of House Tomb 3, 5 and Ceremonial Area 1, see Margaritis 2017; for a fuller description of the cemetery and all its house tombs, see Tsipopoulou 2017; Tsipopoulou forthcoming). House Tomb 4 was constructed in the Prepalatial period and used until the end of the Protopalatial, while House Tombs 2 and 10 date to the Protopalatial period. House Tomb 2 is the largest building, measuring $65 \mathrm{~m}^{2}$ and comprising nine rooms (Figure $3 b$ ). Mortuary activities within this house tomb differed slightly from those in the rest of the cemetery buildings in that a few primary burials were present, which-along with some of the secondary burials-occurred in ceramic containers, namely larnakes and pithoi. This house tomb was also located next to the larger of the two open-air ceremonial areas. House Tomb 4 measures $57.5 \mathrm{~m}^{2}$ and consists of four rooms (Figure 3c), while House Tomb 10 measures $26 \mathrm{~m}^{2}$ and comprises only two rooms (Figure 3d). Though House Tomb 10 constitutes the smallest burial building of the cemetery, it proved to be one of the richest house tombs and provided evidence for some unique architectural features, including a plastered North façade adorned with horns of consecration.

Despite their architectural differences, all three house tombs contained stone and ceramic vessels related to food and drink consumption, as well as grave goods in the form of jewelry, seal stones and metal items/tools made of bronze, gold and silver. These artifacts indicate that ritual activity connected to mortuary practices also took place in the house tombs, in addition to the ceremonial areas at the cemetery. The archaeobotanical data for House Tombs 2, 4 and 10 derive from all the samples collected from within the building, including all levels and all rooms.

\section{Materials and Methods}

The plant remains from the open-air sanctuary at Kophinas, the Fetish Shrine at Knossos Anetaki and the house tombs at Petras all derive from sediment samples collected during excavation of these sites. At the open-air sanctuary and the Fetish Shrine, a 'judgement sampling' strategy was employed (cf. Pearsall 2015), wherein samples were taken at the excavators' discretion-mostly in relation to the presence of charcoal. In contrast, all the excavated sediment from the cemetery at Petras was kept for sampling in order to retrieve small grave goods, such as beads and seal stones, that may have escaped detection on site.

All of the samples from the three sites were transported to INSTAP-SCEC for processing via water flotation using a mechanized version of a modified Ankara machine, as described by French (1971). A single $1 \mathrm{~mm}$ mesh net was used to retain the heavy fractions of the sediments (residues), while a fine calibrated mesh of $0.3 \mathrm{~mm}$ aperture was used to collect the light fractions that contain charred and organic material (flots). Samples were then left to dry in the shade. After processing, the residues were systematically sorted with the naked eye to retrieve any archaeobotanical material that may have evaded the mechanisms of water flotation and to recover small organic material and archaeological artifacts. The flots were analyzed using a low-powered Leica EZ4E stereomicroscope at 8-35× magnification. Both whole seeds and seed fragments were quantified and expressed as absolute counts, while the Minimum Number of Individuals (MNI) was calculated based on characteristic plant parts, such as olive stone points and flax tips. Recorded values of indeterminate and indeterminable plant remains, as well as unidentifiable organic matter, were excluded from this study since they did not contribute to the overall results, whereas 
estimated charcoal values, expressed as relative quantities based on quick scans, were included due to their taphonomic importance. Seed identifications were made through comparison with relevant digital atlases (Cappers et al. 2009; Neef et al. 2012; Sabato and Peña-Chocarro 2021), as well as the INSTAP-SCEC reference collection (compiled by Dr. E. Margaritis and expanded by Dr. M. Scarry and C. Henkel). Taxonomic nomenclature follows Zohary et al. (2012), while terminology and dates for Minoan chronology follow Manning (2010). All images of plant remains presented in this paper were taken using the Leica Image Building software.

It should be noted that analysis of the archaeobotanical assemblages from Kophinas and Knossos Anetaki continues in respect to achieving higher levels of taxonomic recognition of categorized plant macrofossils, such as 'legume sp.' and 'cf. fruit pulp', and identification of indeterminate plant remains. While this work may reveal additional or new plant taxa in the future, these minor results will not affect the current interpretations and conclusions presented in this paper.

\section{Results}

\subsection{Plant Remains from Kophinas, Knossos Anetaki and Petras}

Archaeobotanical analysis involved the examination of 1005 samples collected from the three sites, which produced a total of 1182 charred plant remains (Table 1). Though Kophinas is represented by the fewest number of samples and lowest sample volume, this sample set proved to be the richest in respect to the density of remains per liter of sediment. In contrast, the Petras sample set, which consisted of the largest number of samples and the greatest sample volume, proved to be the least rich. These results likely reflect differences in preservation conditions at each site. In general, the archaeobotanical material from Kophinas and Knossos Anetaki demonstrated fairly decent preservation, with the recovery of tiny plant remains, such as Hypericum sp., and fragile plant parts, such as fruit pulp, while the archaeobotanical material from Petras showed a slightly higher degree of fragmentation, likely due to taphonomic factors, such as trampling associated with the prolonged reuse of the tombs.

Table 1. Summary of analyzed datasets.

\begin{tabular}{cccc}
\hline & Kophinas & Knossos Anetaki & Petras \\
\hline Site type & open-air sanctuary & urban shrine & cemetery \\
Period & Neopalatial-Roman & Final Palatial & Pre- and Protopalatial \\
Number of samples & 7 & 78 & 920 \\
Average sample volume (L) & c.5 5.20 & 514 \\
Number of plant remains & 160 & 508 & 0.03 \\
Average density of remains per liter & 4.57 & 0.65 & c.10 \\
\hline
\end{tabular}

Both the Kophinas and Knossos Anetaki plant assemblages (Tables 2 and 3, respectively) are dominated by fruits and nuts, of which grape (Vitis vinifera L.) is the primary taxon. At Knossos Anetaki, however, agricultural crops make up a further component of the plant material, while these types of remains are completely absent at Kophinas. Additionally, the composition of the Petras assemblage (Table 4) differs from both those of Kophinas and Knossos Anetaki in that agricultural crops form the principal component of the plant material from this site, followed closely by fruits and nuts-with olive (Olea europaea L.) as the main taxon-and oil/condiments-with flax (Linum usitatissimum L.) as the main taxon.

A common feature among the three assemblages is the high presence of fruits and nuts, which are mainly represented by olive, almond (Amygdalus communis L.), grape and fig (Ficus carica L.). Olive is present at all three sites in the form of broken stones, though a larger quantity of this taxon was recovered from Knossos Anetaki, which included whole specimens. Grape is also present at all three sites but represented by different combinations of plant parts at each: pips and fruit at Kophinas; pips and stems at Knossos Anetaki; and pips at Petras. Almond and fig occur at both Knossos Anetaki and Petras but are absent at Kophinas. On the other hand, fruit pulp (likely belonging to grape) appears only in 
the Kophinas samples. Some fruit and nut remains from Kophinas and Petras could not be further identified at present beyond the categorizations of 'nutshell', 'indet. Nutshell', 'indet. Nutlet', 'indet fruit/nutsell' and 'fruit/nutshell type'.

Table 2. Archaeobotanical data for Kophinas (whole/fragment).

\begin{tabular}{|c|c|c|c|c|c|}
\hline \multirow{2}{*}{ Plant Remains } & \multirow{2}{*}{$\begin{array}{c}\text { Context } \\
\text { Number of Samples }\end{array}$} & \multirow{2}{*}{$\begin{array}{c}\text { Pyre } \\
4\end{array}$} & \multirow{2}{*}{$\begin{array}{c}\text { Other } \\
3\end{array}$} & \multirow{2}{*}{\multicolumn{2}{|c|}{ Totals }} \\
\hline & & & & & \\
\hline Type & Taxon & & & Taxon & Type \\
\hline \multirow{10}{*}{ Fruits and Nuts } & Olea europaea (stone) & $0 / 1$ & $0 / 2$ & 3 & \\
\hline & cf. O. europaea (stone) & $0 / 2$ & & 2 & \\
\hline & Vitis vinifera (pip) & 6/94 (MNI: 7) & $0 / 1$ & 101 & \\
\hline & cf. $V$. vinifera (pip) & $0 / 4$ & & 4 & \\
\hline & Fruit pulp (cf. V. vinifera) & $0 / 33$ & & 33 & \\
\hline & Indet. nutshell & $0 / 1$ & & 1 & \\
\hline & Indet. nutlet & $0 / 2$ & $0 / 3$ & 5 & \\
\hline & Indet. fruit/nutshell & $0 / 4$ & $0 / 2$ & 6 & \\
\hline & Fruit/nutshell type & & $0 / 2$ & 2 & \\
\hline & & & & & 157 \\
\hline \multirow{4}{*}{ Herbaceous } & Lamiaceae (cf. Stachys/Salvia sp.) & & $1 / 0$ & 1 & \\
\hline & Lamiaceae & $1 / 0$ & & 1 & \\
\hline & cf. Poaceae (glume) & 1 & & 1 & \\
\hline & & & & & 3 \\
\hline Totals & & 149 & 11 & \multicolumn{2}{|c|}{160} \\
\hline $\begin{array}{l}\text { Charcoal } \\
\text { estimate }\end{array}$ & & $1-1500$ & $1-500$ & & \\
\hline
\end{tabular}

MNI = Minimum Number of Individuals.

Agricultural crops include cereals and pulses. These remains are completely absent at Kophinas but present at Knossos Anetaki and Petras. While barley (Hordeum vulgare L.) is recorded at both sites-with the grains from Knossos Anetaki possibly belonging to the hulled variety - evidence for glume wheats, namely emmer (Triticum turgidum subsp. dicoccum) and einkorn (Triticum monococcum L.), comes only from Knossos Anetaki. This site also produced a single free-threshing cereal grain (Triticum aestivum/Triticum durum or Hordeum vulgare var. nudum) and chaff remains (glume bases and spikelets), some of which are classified as intermediate specimens (T. turgidum subsp. dicoccum/T. monococcum) on account of their poorly preserved state. Furthermore, the degraded nature of some cereals at both Knossos Anetaki and Petras restricted their identification beyond 'cerealia ssp.' In terms of pulses, both Knossos Anetaki and Petras provided evidence for grass pea (Lathyrus sativa). While lentil (Lens culinaris Medik.) is attested at Knossos Anetaki, its identification remains tentative at Petras. There is also a tentative identification of pea (cf. Pisum sp.) at Knossos Anetaki and a tentative identification of bitter vetch (Vicia ervilia) at Petras. The highly fragmented nature of the pulses required the creation of a few intermediate categories at Petras (Lathyrus sativa/Vicia ervilia and Vicia sp./Pisum sp.) and prevented some remains from being classified beyond 'legume sp.' at both sites.

The presence of flax at Petras constitutes the most noticeable distinction among the three assemblages. Numerous seeds from all three house tombs were recovered in both whole and fragmented forms, which are easily recognizable by their distinctive seed tip and the characteristic cell pattern. Many specimens also exhibited large cavities, which are a common feature of charred oily seeds. The MNI calculated for this taxon is 24 specimens, and their identification as representing the cultivated variety was based on the size of the seeds, for which the average is 1.3.68 $\times$ w.1.82 $\times$ t.1.02 $\mathrm{mm}$ (Table 5).

The only wild taxon, the pistacia tree (Pistacia sp.), occurs at Petras, while herbaceous taxa are present at all three sites. The herbaceous specimens recovered from Kophinas comprise two seeds belonging to the mint family (Lamiaceae) and one potential glume from the grass family (Poaceae). At Knossos Anetaki, herbaceous taxa are represented by single seeds of bedstraw (Galium sp.), St. John's wort (Hypericum sp.) and the mint family, as well as a fragment of a grass seed. At Petras, whole seeds of bindweed (Convolvulus sp.) 
and mallow (Malva sp.) were recovered, along with some fragments of seeds belonging to the daphne (Thymelaeaceae) and grass families.

Table 3. Archaeobotanical data for Knossos Anetaki-Fetish Shrine (whole/fragment).

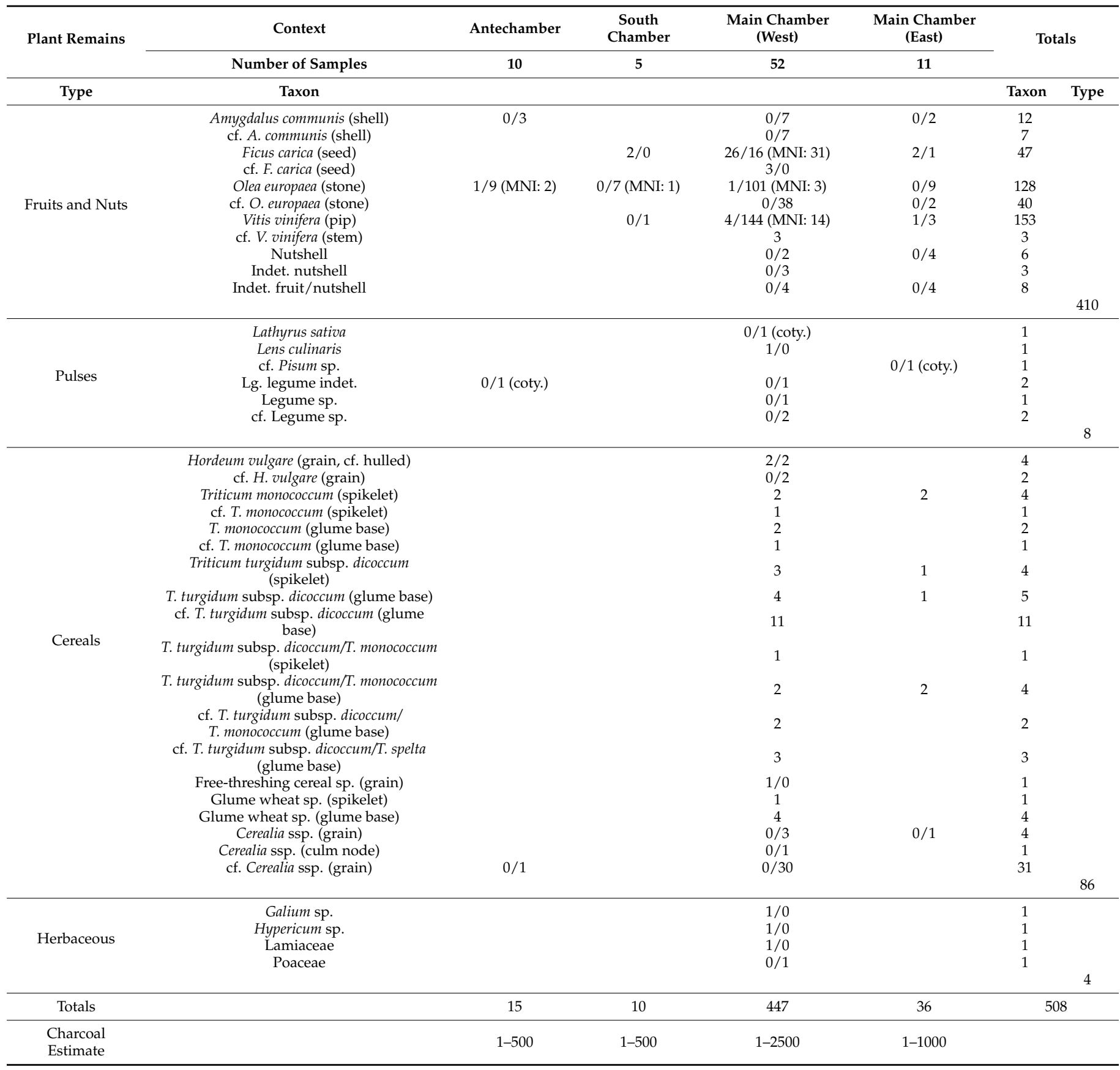

MNI = Minimum Number of Individuals; coty. = Cotyledon. 
Table 4. Archaeobotanical data for Petras (whole/fragment).

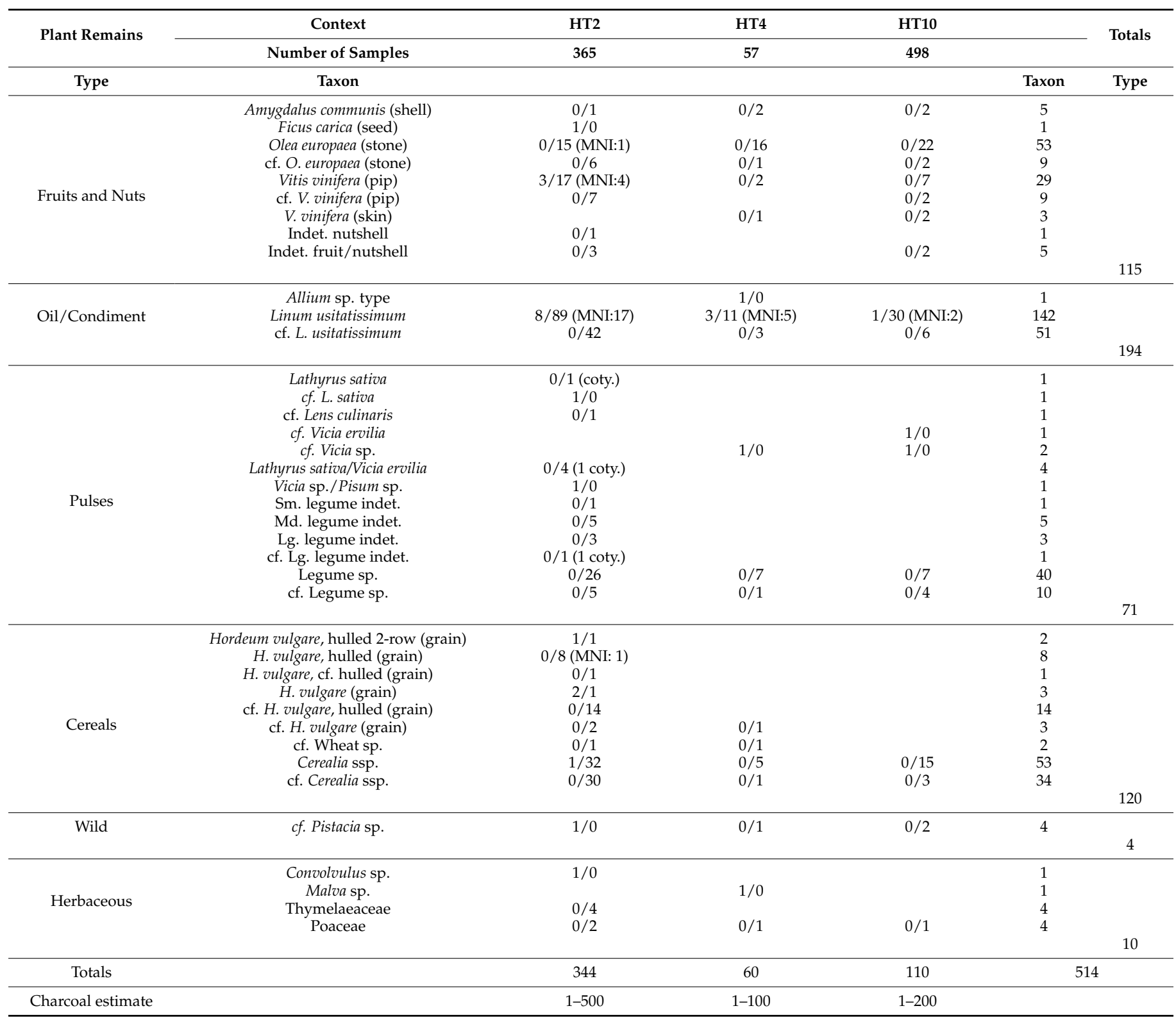

MNI = Minimum Number of Individuals; coty. = Cotyledon; Sm. = Small; Md. = Medium; Lg. $=$ Large.

Table 5. Measurements ( $\mathrm{mm}$ ) of three flax seeds from Petras.

\begin{tabular}{cccc}
\hline Flax & Length & Width (Max.) & Thickness (Max.) \\
\hline Seed 1 & 3.35 & 1.96 & 1.01 \\
Seed 2 & 3.77 & 1.96 & 1.02 \\
Seed 3 & 3.92 & 1.54 & 1.02 \\
Average & 3.68 & 1.82 & 1.02 \\
\hline
\end{tabular}

\subsection{Archaeobotanical Data for the Bronze Age Ritual Arena of Crete and Mainland Greece}

As already mentioned, not much archaeobotanical work has been conducted on prehistoric ritual contexts from Crete up to this point. Of the available published data (Table 6), it appears that there are nine records for the Bronze Age, though seven of these constitute spot finds from early excavations, which were never studied by a specialist (see Hamilakis 1996), and another one is still under study (see Margaritis 2014a). When also considering Bronze Age ritual contexts from Mainland Greece, another four records can be added to the overall 
body of work for the region (Margaritis 2014a, 2014b; Smith et al. 2014; Kotzamani and Livarda 2017), though the situation with these records is similar to those of Crete, in that three of the four are still under study, with only limited preliminary results having been published to date (Margaritis 2014b). In other words, there are only two records-one from Crete and one from Mainland Greece - that currently provide fully published data from actual archaeobotanical studies of Bronze Age ritual contexts in the region, and both of these records represent mortuary sites. In this regard, the archaeobotanical results for the three sites being presented here make a significant contribution to the overall body of published work, and Kophinas and Knossos Anetaki, in particular, allow for a fuller picture of the use of plants in the broader ritual sphere.

\subsubsection{Fruits and Nuts}

According to the current published data, fruits and nuts occur the most often among plant assemblages recovered from ritual contexts in Crete and Mainland Greece. Olive is the dominant taxon and is the only plant remain to appear in both mortuary and non-mortuary ritual contexts. However, other fruits may be absent from the non-mortuary data due to their size, for the records of this type constitute spot finds, and olives-particularly whole stones-are more readily visible with the naked eye during excavation than smaller fruit seeds, such as grape and fig. These smaller seeds have so far only been recovered from the funerary sites of Ayia Sotira on Mainland Greece and Petras on Crete, though whole grape fruits were also discovered at the latter. Almond, on the other hand, does not feature at all among the published ritual contexts from either Crete or Mainland Greece. The results from Kophinas, Knossos Anetaki and Petras, therefore, clearly enrich the current data for the presence of olive, grape and fig at ritual contexts in both regions and provide new evidence for the inclusion of almond among Bronze Age ritual activities on Crete (alongside recent results for almond at the ritual site of Protopalatial/Neopalatial Alonaki-Henkel and Margaritis forthcoming a).

\subsubsection{Crops}

Despite being staples of everyday subsistence, cereals and pulses have so far been poorly represented among the published data for Bronze Age ritual contexts from Crete and Mainland Greece. To date, barley is the only cereal associated with ritual activity on Crete. It was recovered as part of earlier archaeobotanical work at the cemetery of Petras, where it was identified in its hulled variety form (Margaritis 2017). This cereal also occurs at two ritual sites on Mainland Greece: one mortuary (Ayia Sotira) and one non-mortuary (Mt. Lykaion). At the mortuary site, it appears alongside chaff remains of emmer, which could indicate funerary feasting (Smith et al. 2014; Kotzamani and Livarda 2017). Einkorn, on the other hand, is completely absent from the records for both Crete and Mainland Greece. In this respect, the plant assemblage from Knossos Anetaki is extremely significant, since it attests to the use of barley at a non-mortuary site in Crete and provides the first evidence for the presence of both emmer and einkorn at a ritual site on the island. Furthermore, it also offers the first tentative identification for free-threshing cereal at a ritual context within the entire region. 
Table 6. Published archaeobotanical records for Bronze Age ritual sites/contexts on Crete and Mainland Greece (Aspis and Kirrha: Margaritis 2014a; Ayia Sotira: Smith et al. 2014; Kotzamani and Livarda 2017; Mt. Lykaion: Margaritis 2014b; Livari: Margaritis 2014a; Petras: Margaritis 2017; Lebena: Daux 1960; Kamilari: Levi 1976; Anemosphilia: Sakellarakis and Sapouna-Sakellarakis 1981; Poros Heraklion: Lembesi 1967; Zakros: Platon 1971; Knossos Caravan Serai: Evans 1964; Phaistos Liliana: Savignoni 1904).

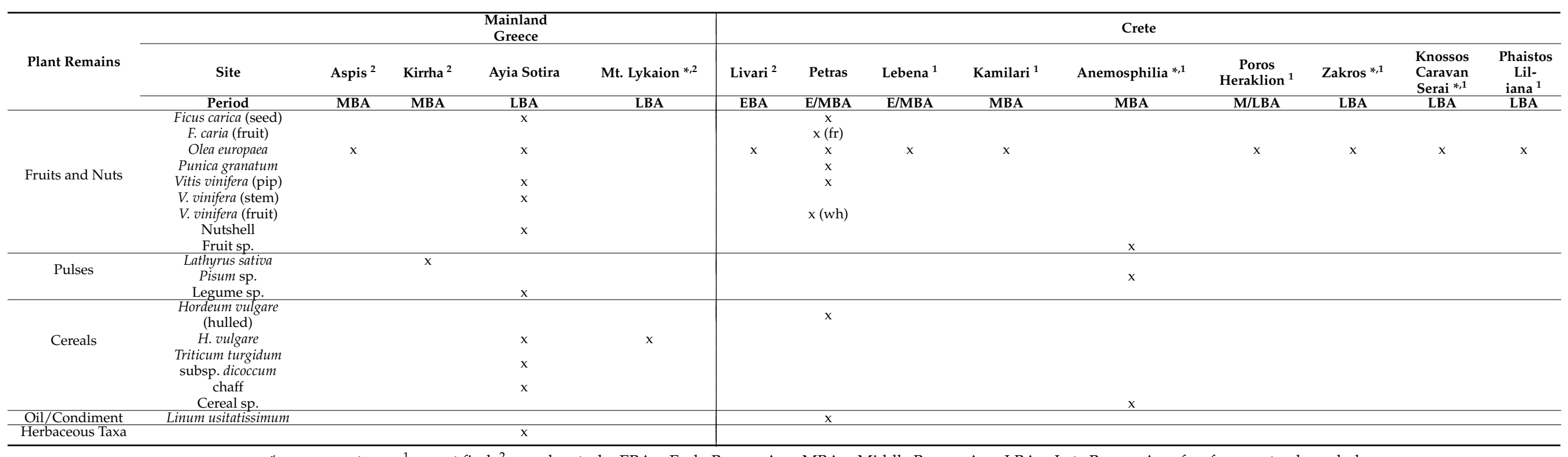

${ }^{*}=$ non-mortuary $;{ }^{1}=$ spot find ${ }^{2}$ = under study; EBA = Early Bronze Age; MBA = Middle Bronze Age; LBA = Late Bronze Age; fr = fragment; wh = whole. 
Pulses are almost entirely absent among the current published data for ritual contexts of Bronze Age Crete and Mainland Greece. To date, the only taxon to be confidently identified from a ritual context is grass pea, which was recovered from a funerary context at Kirrah on Mainland Greece. The data from Ayia Sotira further attest to the presence of pulses in mortuary contexts, though the fragmented state of the remains at this site prevented their more precise identification (Smith et al. 2014; Kotzamani and Livarda 2017). For Crete, pulses are completely absent from the published mortuary records, though present in the non-mortuary record for Anemosphilia. At this site, the presence of pea is reported in the relevant publication, though the archaeobotanical assemblage was not studied by a specialist; it could, therefore, represent another pulse taxon or a combination of pulse taxa, which an image of the finds (Sakellarakis and Sakellarakis 1997), showing some morphologies more closely resembling broad bean than pea, suggests. While an unidentifiable legume fragment has also been recovered from the non-mortuary ritual site of Alonaki (Henkel and Margaritis forthcoming b), the relative scarcity of pulses among the current data gives the impression that this type of plant remain was less important than others when it comes to ritual practices, especially on Crete. The Knossos Anetaki and new Petras data change this picture entirely, demonstrating that a variety of different pulses did play a role in mortuary and non-mortuary ritual practices during the Bronze Age.

\subsubsection{Herbaceous Taxa and Oil/Condiment Seeds}

The archaeobotanical records for Bronze Age ritual contexts in Crete and Mainland Greece have so far only recorded the presence of herbaceous taxa at the funerary site of Aiya Sotira on Mainland Greece and the recovery of oil/condiment seeds from previously studied contexts at the cemetery of Petras in Crete. The lack of herbaceous taxa from ritual contexts within the region is somewhat surprising, as these types of seeds are often at least present in plant assemblages as agricultural weeds or as intrusions by the local flora. In fact, the latter situation seems to explain the presence of herbaceous taxa among both the Ayia Sotira assemblage (Smith et al. 2014; Kotzamani and Livarda 2017) and the current Petras assemblage, since repeated use of the tombs at these two sites could have easily transported seeds from the local vegetation inside the mortuary buildings. Given that the majority of the other records comprise spot finds and limited preliminary results, it is not surprising that herbaceous taxa were not recorded, for these seeds are usually too small to notice with the naked eye and do not often merit mention as part of initial findings. The data for Kophinas and Knossos Anetaki demonstrate that herbaceous seeds were also present at non-mortuary ritual contexts, and the specific taxa recovered from these two sites are suggestive of their intentional use in some of the activities that took place there (see below).

The only oil/condiment seeds to be recovered from a ritual context in either Crete or Mainland Greece are those of flax at the cemetery of Petras. Both the previous and the current archaeobotanical work for this site has revealed the remains of flax, for which the number of recovered seeds constitutes the largest quantity of flax found to date at a single site on Crete (Henkel et al. forthcoming). Flax was also recently found at the non-mortuary site of Alonaki, though this find consisted of only a single broken seed, which could not be confidently identified as representing the cultivated species or being involved in ritual activity (Henkel and Margaritis forthcoming a). The recovery of well-preserved flax seeds from several different house tombs at Petras suggests its intentional use for ritual activity at this site and hints at its special significance in relation to this site (see below).

\section{Discussion}

Kophinas, Knossos Anetaki and Petras consist of three ritual sites that were located at different places within the Cretan landscape.

Yet, all three are similar in that they produced charred archaeobotanical assemblages. A contextualization of these remains, coupled with a careful consideration of associated 
taphonomic factors, can help tease out more particulars regarding the specific ritual activities that made use of this plant material.

At Kophinas, the vast majority of the plant remains came from 'pyre' samples. This pyre, an ash layer that covered an area of roughly $3 \times 3 \mathrm{~m}$, occupied a central place within the open-air sanctuary next to a built platform. The recovery of grape remains, in the form of pips (whole and fragmented) with fruit pulp still adhered to their exterior surfaces and loose pieces of fruit pulp (Figure 4), indicates that whole fruits were subjected to the flames of this pyre, possibly in the form of a plant sacrifice. Ancient ritual practices often involved the act of sacrifice, which is defined as the purposeful destruction of living beings or inanimate objects as a means of creating a relationship between those conducting this activity (the living) and its recipient (those of the other worlds) (Insoll 2011; Verhoeven 2011). The use of fire as a mechanism of destruction at Kophinas suggests that the recipient of the sacrifice may have been a deity or deities, since some ancient cultures regarded fire as a divine messenger (Kaliff 2011), likely due to the fact that its smoke ascends into the sky (Soetens 2009). In this respect, Kophinas-as an open-air site situated at a higher elevation - provides an ideal location for this type of ritual activity, and its archaeobotanical remains potentially serve as the earliest evidence for the occurrence of a plant sacrifice in the Aegean region. The only other documented case of a Bronze Age plant sacrifice comes from the Sanctuary at Mt. Lykaion on Mainland Greece (Margaritis 2014b), which dates to the Mycenaean period. All the other Greek examples date to either the first millennium BC or the Roman period (Megaloudi 2005), many of which are also dominated by fruits. While the recovery of a few Hellenistic sherds from the ash layer at Kophinas creates some uncertainty regarding the true date of the plant remains, these finds still provide evidence for the first plant sacrifice attributed to ancient Crete.

(a)

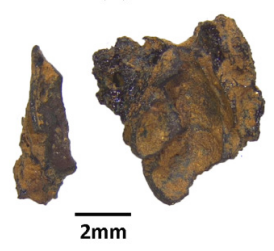

(b)

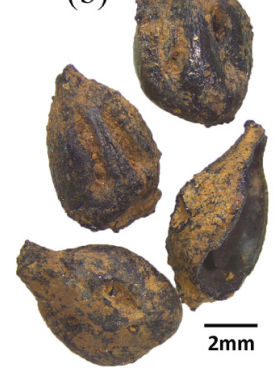

(c)

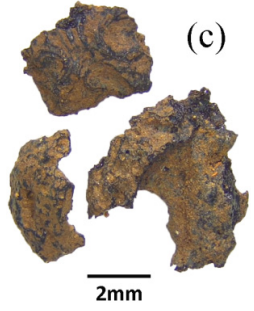

Figure 4. Grape (Vitis vinifera) remains from Kophinas: (a) pip fragments with fruit pulp; (b) whole pips with fruit pulp; (c) loose pieces of fruit pulp.

On the basis of experimental work (Margaritis and Jones 2006), the grape remains from the pyre could represent either raisins or small fresh grapes. The recovery of olive stone fragments in and around the pyre could suggest that this fruit also featured as part of the plant sacrifice, though the number of these remains is low, and they could equally result from feasting activities. Both grape and olive, however, likely grew within the relative vicinity of Kophinas, and it is interesting to consider whether these fruits comprise deliberately selected plants for the sacrifice or fruits of opportunity. Certainly, as deliberately selected plants, both grape and olive would have held a symbolic significance to the Minoans during the Neopalatial period, since they represented the social and economic lifeblood of the culture through their extensive exploitation as cash crops for the production of olive oil and wine.

The recovery of herbaceous seeds belonging to the Lamiaceae family suggests that plants with aromatic properties were also burned on the pyre, perhaps for the purpose of creating a fragrant atmosphere that activated the olfactory faculties of spectators. When considering the activities at Kophinas from the perspective of the archaeology of the senses, all five of the audience's senses may have been stimulated during ritual events. The heat 
generated by the pyre, the vision of burning plant sacrifices and the noise that accompanied them probably acted as tactile, visual and auditory stimuli. Additionally, if the consumption of food and drink accompanied the ritual practices, as the ceramic assemblage suggests, then this would have also triggered the guests' sense of taste. The simultaneous activation of all the senses during the sacrificial event would have made for an impactful performance that created a powerful memory of this socioreligious experience.

The bulk of the archaeobotanical material recovered at Knossos Anetaki came from samples collected in the West half of the Main Chamber of the Fetish Shrine, between the central altar and the bench with the fetish idols. This same area produced several intact conical cups and kalathoi-Minoan cultic vessels used for the purpose of making offerings (Day 2009; Evans 1964; Tsipopoulou 2009). While these vessels did not contain any finds at the time of excavation, their over-turned, in situ position indicates that their original contents may have been the plant remains and that these were spilled out onto the floor prior to deposition.

The plant material mainly consisted of fruits and nuts, cereals and legumes (Figure 5) the same type of plant remains that regularly occur within domestic contexts on the island; some as early as the Neolithic period and others since the Pre- or Protopalatial periods (for a review of plant taxa presence on Crete, see Livarda and Kotzamani 2013). The lack of rarer plant taxa that could have had specific ritual meanings or functions, along with the presence of grape stems, weed seeds and chaff remains, suggests that the plant material was meant to represent everyday food stores.

(a)

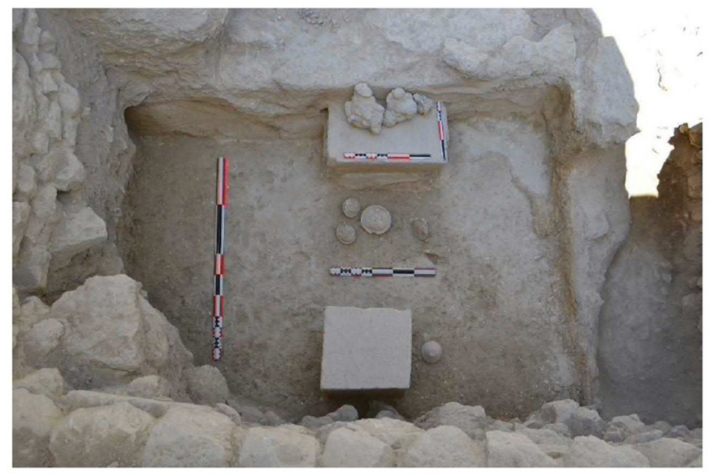

(b)

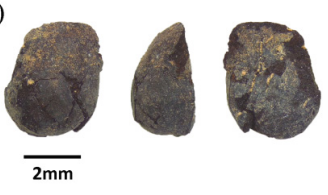

(d)

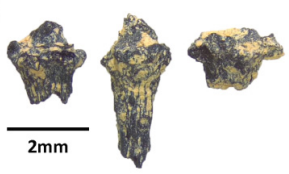

(c)

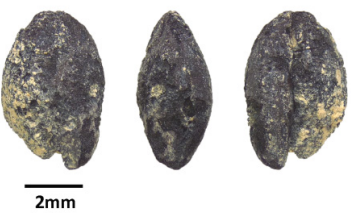

(e)

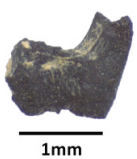

(f)

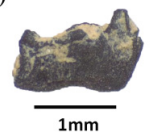

(i)

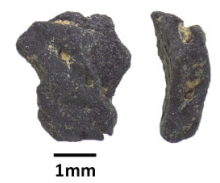

Figure 5. Plant remains from the Fetish Shrine at Knossos Anetaki: (a) view of West half of the Main Chamber of the Fetish Shrine; (b) grass pea (Lathyrus sp.) cotyledon; (c) barley grain (Hordeum vulgare cf. hulled); (d) grape (Vitis vinifera) stems; (e) emmer (Triticum turgidum subsp. diococcum) spikelet; (f) einkorn (Triticum monococcum) spikelet; (g) whole olive stone (Olea europaea); (h) fig seed (Ficus carica); (i) almond (Amygdalus communis) shell fragment. 
Interestingly, the estimated charcoal values associated with the plant remains from the Fetish Shrine are fairly low given the number of samples and volume of sediment, which seems to indicate that the carbonization of the plant remains likely did not occur in situ. The fact that the excavation of the shrine did not reveal any traces of burning on its floor, or unearth any hearths, further reinforces this notion. Given the character of the assemblage and the inclusion of some charcoal, the remains could either represent the offering of small portions of domestic hearth debris or food offerings that were intentionally charred elsewhere prior to their deposition within the Fetish Shrine. If the latter, then the charred food offerings could constitute a symbolic plant sacrifice that took place under semi-controlled conditions in order to ensure the survival of some remains, which could be collected and deposited in a more permanent ritual location after the event. In this case, it is likely that a pyre, or some other wood-burning fire, would have been used for this activity, since charcoal was present along with the plant remains. Due to the small, enclosed nature of the Fetish Shrine, the symbolic sacrifice of food offerings may have occurred in a more open public space where a larger number of spectators could readily observe the ritual event. Afterward, the remains may have been placed in the Fetish Shrine as a mnemonic device that reminded visitors of this socioreligious event.

As hearth debris or deliberately charred plant foods, the offerings may reflect the urban environment of the Fetish Shrine and the circumstances of the period, denoting ritual activity in connection to a local harvest festival or community concerns regarding the fruitfulness of agricultural yields. Textual and palaeoenvironmental evidence indicates that drought and famine were suddenly becoming an issue in various areas of the Mediterranean region toward the end of the Late Bronze Age (Cline 2015; Finne et al. 2017; Kaniewski et al. 2013). While none of written sources record such events for Crete, increased aridity and drought on the island at this time is reflected by the disappearance of Tilia pollen (drought-intolerant taxa) in the Delphinos and Kournas cores taken from Western Crete (Moody 2005, 2014; for core data, see Bottema and Sarpaki 2003). On the other hand, the domestic quality of the ritual plant remains from the Fetish Shrine may relate to some other unknown reason, since archaeobotanical assemblages of a similar character have also been recovered from mortuary sites on the island (Flint-Hamilton 2016; Margaritis 2017).

The Petras plant remains were primarily retrieved from levels either on or just above the floors of specific spaces within each of the house tombs: Rooms 1-4 and 9 of House Tomb 2; Rooms 1 and 3 of House Tomb 4; and Room 2 of House Tomb 10 (Henkel et al. forthcoming). Most of these rooms form spaces connected to the entrance of the house tombs, with the exception of Room 2 in House Tomb 2, Room 1 in House Tomb 4 and Room 2 in House Tomb 10. Before later building additions to House Tomb 4, however, this tomb may have originally consisted of a single room (Room 1), meaning that this space did once connect to an entrance. Likewise, the small size of House Tomb 10 places Room 2 of this building in close proximity to its entrance. As such, some of the plant remains recovered from these tombs, such as the fruits, nuts, cereals and pulses, which have a domestic quality to them, could be related to funerary feasting events that took place in the ceremonial areas of the site. Since each of the house tombs abuts one of these open spaces, food debris could have easily ended up in the mortuary buildings via taphonomic transport processes. Given the complex taphonomy of the house tombs themselves, including reuse and secondary manipulation of the human remains, untangling the formation processes that created the plant assemblage proves complicated, and other possibilities also exist.

Archaeological and osteological information indicates that the plant remains do not result from primary fire destruction within the house tombs or from cremation practices, for which there is no evidence at Petras. Instead, the low charcoal values associated with the samples again suggest a secondary episode-or rite-involving the burning of the plant material, which perhaps occurred as deposition in parallel with the human bones, or later, in some of the many separate interventions demonstrated by the analysis of the human remains. In these numerous episodes, fire was used for both hygienic and symbolic reasons 
to cleanse some of the body parts (Kiorpe and Triantafyllou forthcoming). The charring of the seeds could have occurred during this ritual activity or another separate one, such as a burning rite on the floor of the tomb, though no traces of burning were discovered during excavation. Alternatively, the burning rite could have taken place outside of the house tombs, perhaps in a household hearth where one of the dead had lived, since the assemblage does contain plant remains often associated with cooking accidents (cereals and pulses) and the use of fuel (almond shells and olive stones), or in a more public area where this activity could be witnessed by more members of the community.

The presence of flax (Figure 6), however, plays a significant role in the interpretation of the material. This plant species is not a common find among domestic contexts, unless it had been used for food. In such cases, however, one would expect to find far fewer remains, since the oily content of this seed causes this plant taxon to completely burn up more readily than others (Margaritis 2020; Valamoti 2011). It is possible, therefore, that flax was symbolically sacrificed - that is, carefully burnt in a manner that did not destroy the seeds-in order to preserve the remains and deposit them as an offering within the tombs. This choice of plant material as an offering could relate to the identity of the dead in that cultivated flax, which can be used to extract oil from its seeds, to make linen from its fibers and for medicinal or culinary purposes, may have represented the social and economic livelihood of a kin group at Petras, or its community at large.

(a)

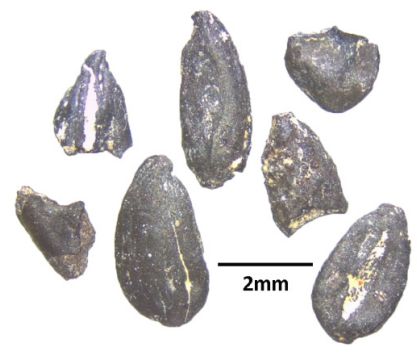

(b)

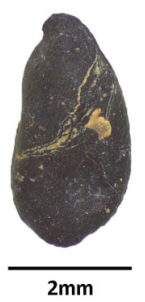

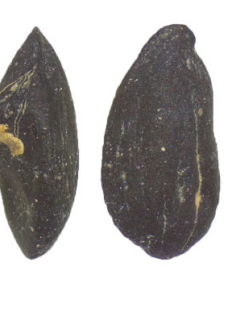

Figure 6. Flax (Linum usitatissimum) from Petras: (a) whole and fragment seeds; (b) detailed views of a whole seed.

The new archaeobotanical results for Kophinas, Knossos Anetaki and Petras offer some important insights into the use of plants within the wider ritual landscape of Bronze Age Crete. Firstly, it appears that at all three sites, plants were not just involved in rituals but intentionally burnt as part of the ritual acts. Given the semiotic nature of fire, the choice of this medium as a component of Minoan ritual is not surprising. To ancient cultures, fire would have seemed magical or mystical, since it could seemingly appear out of nowhere when one banged two rocks together or from the sky via lightning, which would have made it seem like a gift from the divine; fire was also related to notions of life and death in that it was necessary for subsistence (cooking food) but at the same time could destroy and kill things (Kaliff 2011). In this sense, the role of fire at the ritual sites of Kophinas, Knossos Anetaki and Petras seems fitting. Secondly, all three sites also hint at a potential socioreligious aspect to ritual activities involving the burning/charring of plant remains, a feature of Minoan religion that has already been identified via material culture and iconographic studies but is reaffirmed by the archaeobotanical evidence, specifically that of Knossos Anetaki and Petras where taphonomic factors indicate that the ritual charring of plant material did not take place in socially exclusive spaces. Thirdly, the selection of plants for the ritual activities at all three sites potentially involved emotive and/or symbolic purposes designed to create strong mnemonic links to religion and to express each community's relationship with plants.

These three aspects of the Kophinas, Knossos Anetaki and Petras archaeobotanical assemblages fit well with the rest of the plant data for ritual contexts of Bronze Age Crete. While it is hard to compare results with the spot finds of charred olives from ritual contexts 
on the island, some of these remains also suggest the intentional charring of plant material in connection with ritual activity, such as those in the sarcophagus at Phaistos Liliana and a bowl at Zakros. In both cases, the pottery vessels in which they were discovered likely do not constitute their primary place of charring but rather the contexts in which they were intentionally deposited after being charred elsewhere. Results for Livari and previously studied ritual contexts at Petras also indicate the deliberate charring of plant material for ritual deposition in mortuary contexts (Margaritis 2014a, 2017). The fact that olives are consistently present among the previously published records and the new result for Kophinas, Knossos Anetaki and Petras suggest that this taxon did not just hold domestic and economic importance on Crete but possibly also a ritual significance. The previous archaeobotanical work for Petras also concluded that feasting and symbolic plant choices formed part of the ritual practices at this site (Margaritis 2017). Furthermore, researchers' work on plant remains from the Neopalatial Minoan-type peak sanctuary at Stelida on the island of Naxos in the Cyclades has recently suggested the use of aromatic plant taxa as part of ritual activities that took place at this site (Carter et al. 2021).

Despite the scarcity of records for Mainland Greece, the picture is somewhat similar for this part of the Aegean. Archaeobotanical material recovered from the ash altar at the Sanctuary of Zeus on Mt. Lykion in the Peloponnese provides evidence for intentional charring of plant food offerings. By assessing the charring conditions of faunal material recovered from the same context as the plant remains, it was determined that the temperatures at which the animal bones were burnt exceeded those that would permit the preservation of plant material before they turned to ash, indicating that they were deliberately charred in a separate episode before their deposition within this ritual context (Margaritis 2014b). Likewise, the carbonized archaeobotanical material recovered at Ayia Sotira was not associated with any traces of fire (Kotzamani and Livarda 2017), which could indicate their intentional charring as well. A social context to the ritual activities at Mt. Lykaion is communicated through the use of open-air areas, such as the ash altar, and the recovery of a large number of drinking vessels (Romano and Voyatzis 2014). Ritual feasting is also hypothesized to have taken place in connection with funerary rites at Ayia Sotira, and this activity may have occurred in the dromoi areas of the chamber tombs (Kotzamani and Livarda 2017) where there was space to accommodate larger numbers of participants.

A final observation regarding the archaeobotanical material from ritual sites in Crete and Mainland Greece as a whole pertains to the use of plant taxa commonly associated with domestic contexts, such as cereals and pulses. While previous work at Petras and Kavousi Vronda on Crete have already hinted at this phenomenon, the results for Knossos Anetaki and the current contexts at Petras confirm it and reveal an even broader suite of plant remains engaged in ritual activities of the period than was previously known. Despite the paucity of published records for Mainland Greece, the same situation is also suggested by the recovery of cereal and pulse remains at Ayia Sotira and barley remains at Mt. Lykaion. The use of food plants for ritual purposes is not particular to the Aegean region, occurring also in Central Europe (Außerlechner 2021) and Anatolia (Fairbairn et al. 2019). The observation that cereals, pulses, fruits and nuts often appear in a variety of combinations and quantities at ritual sites in general (Palmer and Van der Veen 2002) suggests that there is rarely a simple correlation between particular foods and specific social activities. The use of the same plants can be significant on a number of levels, from daily consumption to special ritual occasions and funerary events.

\section{Conclusions}

The new archaeobotanical results for Kophinas, Knossos Anetaki and Petras significantly expand the current plant data for ritual sites on Crete. The archaeobotanical evidence from these sites suggests that plant sacrifice, symbolic plant sacrifice and the intentional charring of seeds all formed part of ritual plant use during the Bronze Age. In synthesizing the new data and comparing it with previous work conducted for mortuary context on 
the island, some common aspects among the different ritual activities involving plants become apparent:

1. The key element is the use of fire. The charred seeds could be a symbolic mode of reference to the process of transformation: any kind of rite of passage includes some kind of transformative process. The plant remains in the contexts mentioned here have in common the deliberate act of transformation and consumption occasioned by burning. It is beyond any doubt that if the plant remains had been deposited raw, they would not have survived. The important factor in this case then is not simply the deposition of plant material but the deposition of charred plant material (Margaritis 2014a). Fire does not merely transform wood into fuel but plays a key role in effecting major changes in basic aspects of life, including: the cooking of food, the creating of agricultural land, the firing of pots and the making and shaping of metals. The role of fire in destroying (or changing the state of) artifacts has been noted since the Upper Palaeolithic. A characteristic example is the destruction of axes in Neolithic Scandinavia, not utterly but in a way that preserves them in lumps as large as possible, even after their fragmentation by fire (Larsson 2004).

2. In this set of contexts, there is no clear evidence that specific species or 'exotic' plants were especially connected with the ritual activities; no certain patterns have been revealed. All the species present are also found in domestic contexts and everyday ones. The boundary, therefore, between ritual and domestic when it comes to deposition of plant remains is not species-dependent. Such finds could represent part of the daily life, be connected to the harvest or the by-production of some agricultural practice. It has also been suggested that the deposition of food could represent the conceptual presence of the domestic hearth, where the core of the household's cooking activities took place. Such an identification creates a link between the everyday domestic routines with those in another world, blurring the lines between ritual and domestic actions (Margaritis 2018).

As this paper tried to demonstrate, theoretical and methodological frameworks that go beyond the traditional conceptualization of plant remains as simple foodstuffs are necessary for approaching the meaning/significance behind ritual plant use. Conducting archaeobotanical work of this nature, however, presupposes the availability of suitable sample sets. There is still progress to be made in this regard, which requires effort on the part of archaeobotanists and archaeologists alike to ensure that (a) robust sampling strategies are implemented at ritual sites and (b) important ritual contexts are recognized, recorded and sampled during excavation.

Author Contributions: Conceptualization, C.H. and E.M.; methodology, C.H.; software, C.H.; validation, C.H. and E.M.; formal analysis, C.H. and E.M.; investigation, C.H.; resources, C.H. and E.M.; data curation, C.H. and E.M.; writing-original draft preparation, C.H.; writing-review and editing, C.H. and E.M.; visualization, C.H.; supervision, E.M.; project administration, E.M.; funding acquisition, E.M. All authors have read and agreed to the published version of the manuscript.

Funding: This research was funded by The Cyprus Institute and the Institute for Aegean Prehistory Study Center for East Crete (INSTAP-SCEC).

Institutional Review Board Statement: Not Applicable.

Informed Consent Statement: Not Applicable.

Data Availability Statement: Plant data for Knossos Anetaki will also be available in (Henkel and Margaritis forthcoming a); plant data for Petras will also be available in (Henkel et al. forthcoming); and plant data for all three sites will be available in the forthcoming doctoral thesis of C. Henkel.

Acknowledgments: We are grateful to Alexandra Karetsou (director of Kophinas excavations), Athanasia Kanta (director of the Knossos Anetaki excavations) and Metaxia Tsipopoulou (director of the Petras excavations) for not only allowing us to study the archaeobotanical assemblages from their exceptional sites but for also permitting the material to form part of C. Henkel's doctoral research, which is being carried out at The Cyprus Institute's Science and Technology in Archaeology and 
Culture Research Center. We would also like to thank the Institute for Aegean Prehistory Study Center for East Crete (INSTAP-SCEC) and its director, Tom Brogan, for providing the lab space and resources necessary to study the plant assemblages, as well as Matina Papadaki for floating all of the sediment samples, Dominika Kofel for conducting some initial archaeobotanical analysis on the Petras and Knossos Anetaki flots and Alexia Spiliopoulou for providing ceramic information regarding the stratigraphy at Kophinas. Our appreciation is also extended to the reviewers, who provided useful comments on an earlier draft of this paper that helped shape it into its present form.

Conflicts of Interest: The authors declare no conflict of interest.

\section{References}

Alexiou, Stulianos. 1963. H Archaiologiki Kinisis en Kriti kata to 1961. Kpitika Chronika 17: 382-94.

Außerlechner, Marlies. 2021. Plant Use and Rites at Burnt Offering Sites in the Eastern Alps during the Bronze and Iron Ages. Vegetation History and Archaeobotany 30: 155-70. [CrossRef]

Bottema, Sytze, and Anaya Sarpaki. 2003. Environmental change in Crete: A 9000-year record of Holocene vegetation history and the effect of the Santorini eruption. The Holocene 13: 733-49. [CrossRef]

Bradley, Mark. 2015. Smell and the Ancient Sense. London and New York: Routledge.

Cappers, Rene, Reinder Neef, and Renee Bekker. 2009. Digital Atlas of Economic Plants. Groningen: Barkhuis \& Groningen University Library.

Carter, Tristan, Kristine Mallinson, Vagia Mastrogiannopoulou, Daniel A. Contreras, Charlotte Diffey, Claudette Lopez, Marie N. Pareja, Georgia Tsartsidou, and Dimitris Athanasoulis. 2021. A New Minoan-Type Peak Sanctuary on Stelida, Naxos. Journal of Greek Archaeology 6: 60-99. [CrossRef]

Cline, Eric. 2015. 1177 BC: The Year Civilization Collapsed. Princeton: Princeton University Press.

Daux, Georges. 1960. Lébèn, in Chronique des fouilles 1959. Bulletin de Correspondance Hellénique 84: 841-46.

Day, Lesley. 2009. Ritual Activity at Karphi: A Reappraisal. Hesperia Supplements 42: 137-51.

Evans, Arthur. 1964. The Palace of Minos. Part I. New York: Biblo and Tannen, vol. II.

Fairbairn, Andrew, Nathan Wright, Mark Weeden, Gojko Barjamovic, Kimiyoshi Matsumura, and Ron Rasch. 2019. Ceremonial plant consumption at Middle Bronze Age Büklükale, Kırıkkale Province, central Turkey. Vegetation History and Archaeobotany 28: 327-46. [CrossRef]

Finne, Martin, Karin Holmgren, Chuan-Chou Shen, Hsun-Ming Hu, Meighan Boyd, and Sharon Stocker. 2017. Late Bronze Age Climate Change and the Destruction of the Mycenaean Palace of Nestor at Pylos. PLoS ONE 12: e0189447. [CrossRef] [PubMed]

Flint-Hamilton, Kimberly. 2016. The Paleoethnobotany of Vronda. In The Late Minoan IIIC Settlement at Vronda: Specialist Reports and Analyses. Edited by Geraldine Gessel and Lesley Day. Prehistory Monographs 52, Kavousi IIC. Philadelphia: INSTAP Academic Press, pp. 181-93.

French, David. 1971. An Experiment in Water-Sieving. Anatolian Studies 21: 59-64. [CrossRef]

Gesell, Geraldine. 1985. Town, Place and House Cult in Minoan Crete. Studies in Mediterranean Archaeology. Goteberg: Paul Astroms Forlag, vol. LXVII.

Hamilakis, Yannis. 1996. Wine, Oil and the Dialects of Power in Bronze Age Crete: A Review of the Evidence. Oxford Journal of Archaeology 15: 1-32. [CrossRef]

Hamilakis, Yiannis. 2014. Archaeology of the Senses: Human Experience, Memory, and Affect. Cambridge: Cambridge University Press. [CrossRef]

Hamilakis, Yiannis, and Susan Sherratt. 2012. Feasting and the Consuming Body in Bronze Age Crete and Early Iron Age Cyprus. British School at Athens Studies 20: 187-207.

Henkel, Carly. 2021. Seeds of Ritual: An Archaeobotanical Approach to Investigating Ritual Activity in Bronze Age Crete. Kentro: The Newsletter of the INSTAP Study Center for East Crete 24: 21-25.

Henkel, Carly, and Evi Margaritis. forthcoming a. Plant Remains from the Fetish Shrine: Aspects of Ritual Food Offerings from Late Bronze Age Crete. In The Religious Center of the City of Knossos, Volume 1: The Fetish Shrine. Edited by Athanasia Kanta. Philadelphia: INSTAP Academic Press.

Henkel, Carly, and Evi Margaritis. forthcoming b. Food for Thought: The Archaeobotanical Study of Alonaki, Juktas. In Juktas, Volume 1: The MM III Building Complex (at Alonaki). Edited by Alexandra Karetsou. Philadelphia: INSTAP Academic Press.

Henkel, Carly, Dominika Kofel, and Evi Margaritis. forthcoming. Plant Deposition in the House Tombs of Petras. In The House Tombs 2, 4 and 10 from Petras. Edited by Metaxia Tsipopoulou. Philadelphia: INSTAP Academic Press, Institute for Aegean Prehistory Monographs.

Insoll, Timothy. 2011. Sacrifice. In The Oxford Handbook of the Archaeology of Ritual and Religion. Edited by Timothy Insoll. Oxford: Oxford University Press, pp. 151-65.

Kaliff, Anders. 2011. Fire. In The Oxford Handbook of the Archaeology of Ritual and Religion. Edited by Timothy Insoll. Oxford: Oxford University Press, pp. 51-62.

Kaniewski, David, Elise Van Campo, Joel Guiot, Sabine Le Burel, Thierry Otto, and Cecile Baeteman. 2013. Environmental Roots of the Bronze Age Crisis. PLoS ONE 8: e71004. [CrossRef] 
Kanta, Athanasia, ed. forthcoming. The Religious Center of the City of Knossos, Volume 1: The Fetish Shrine. Philadelphia: INSTAP Academic Press.

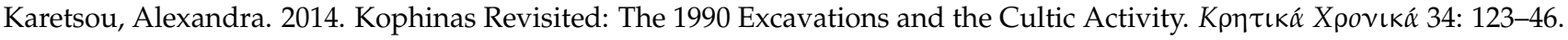

Karetsou, Alexandra. 2018. Clay Boat Models from the MMIII Peak Sanctuary of Kophinas. In Mediterranea Itinera: Studies in Honour Lucia Vagnetti. Edited by Marco Bettelli, Maurizio Del Freo and Gert Jan van Wijngaarden. Rome: CNR-Istituto Di Studi Sul Mediterraneo Antico, pp. 165-80.

Kiorpe, Sotiria, and Sevi Triantafyllou. forthcoming. Preliminary Observations on the Osteological Assemblages of House Tomb 4 and House Tomb 10. In The House Tombs 2, 4 and 10 from Petras. Edited by Metaxia Tsipopoulou. Philadelphia: INSTAP Academic Press, Institute for Aegean Prehistory Monographs.

Kotzamani, Georgia, and Alexandra Livarda. 2017. Archaeobotanical Remains. In Ayia Sotira: A Mycenean Chamber Tomb Cemetery in the Nemea Valley, Greece. Edited by R. Angus, K. Smith, Mary K. Dabney, Evangelia Pappi, Sevasti Triantaphyllou and James C. Wright. Prehistoric Monographs 56. Philadelphia: INSTAP Academic Press, pp. 139-45.

Larsson, Lars. 2004. Axeheads and Fire: The Transformation of Wealth. In Lithics in Action. Edited by Elizabeth Walker, Francis Wenban-Smith and Frances Healy. Oxford: Oxbow Books, pp. 197-205.

Lembesi, Angeliki. 1967. Anaskaphi Spilaiodous Taphou eis Poron Irakleiou. Praktika 1967: 195-209.

Levi, Doro. 1976. Festòs e la Civiltà Minoica. Roma: Edizioni dell'Ateneo.

Livarda, Alexandra, and Georgia Kotzamani. 2013. The Archaeobotany of Neolithic and Bronze Age Crete: Synthesis and Prospects. The Annual of the British School at Athens 108: 1-29. [CrossRef]

Livarda, Alexandra, and Richard Madgwick. 2018. Ritual and Religion: Bioarchaeological Perspectives. In The Bioarchaeology of Ritual and Religion. Edited by Alexandra Livarda, Richard Madgwick and Santiago Riera Mora. Oxford: Oxbow Books, pp. 1-13.

Lupack, Susan. 2010. Minoan Religion. In The Oxford Handbook of the Bronze Age Aegean. Edited by Eric Cline. Oxford: Oxford University Press, pp. 263-76. [CrossRef]

Manning, Stuart. 2010. Chronology and Terimnology. In The Oxford Handbook of The Aegean Bronze Age (c. 3000-1000 BC). Edited by Eric Cline. Oxford: Oxford University Press, pp. 11-28.

Margaritis, Evi. 2014a. Acts of Destruction and Acts of Preservation: Plants in the Ritual Landscape of Prehistoric Greece. In PHYSIS: L'Environnement Naturel et La Relation Homme-Milieu Dans Le Monde Egeen Protohistorique; Actes de La 14e Rencontre Egeenne Internationale, Paris, Institut National d'Histoire de L'Art (INHA), 11-14 Decembre 2012. Edited by Gilles Touchais, Robert Laffineur and Francoise Rougemont. Leuven-Liege: Peeters, Aegeum 37, pp. 279-85.

Margaritis, Evi. 2014b. Appendix 4: Archaeobotanial Data. In 'Mt. Lykaion Excavation and Survey Project, Part 1: The Upper Sanctuary', by David Romano and Mary Voyatzis. Hesperia 83: 642-43.

Margaritis, Evi. 2017. The Plant Remains of the House Tombs at Petras: Acts of Destruction, Transformation and Preservation. In The Pre-and Protopalatial Petras, Siteia Cemetery in Context. Edited by Metaxia Tsipopoulou. Arhuis: Arhuis Univeristy Press, Monographs of the Danish Institute at Athens, vol. 21, pp. 225-36.

Margaritis, Evi. 2018. The Plant Remains from Alepotrypa: Use, Discard and Structured Deposition. In Neolithic Alepotrypa Cave in the Mani, Greece. Edited by Anastasia Papathanasiou, William Parkinson, Daniel Pullen, Michael Galaty and Panagiotis Karkanas. Oxford: Oxbow, pp. 316-26.

Margaritis, Evi. 2020. Archaeobotanical Remains. In Alatzomouri Pefka: A Middle Minoan IIB Workshop Making Organic Dyes. Philadelphia: INSTAP Academic Press, pp. 95-97.

Margaritis, Evi, and Martin Jones. 2006. Beyond Cereals: Crop Processing and Vitis Vinifera L. Ethnography, Experiment and Charred Grape Remains from Hellenistic Greece. Journal of Archaeological Science 33: 784-805. [CrossRef]

Marinatos, Nanno. 1993. Minoan Religion: Ritual, Image and Symbol. Columbia: University of South Carolina Press.

Mee, Christopher. 2010. Death and Burial. In The Oxford Handbook of the Bronze Age Aegean. Edited by Eric Cline. Oxford: Oxford University Press, pp. 277-90. [CrossRef]

Megaloudi, Fragkiska. 2005. Burnt Sacrificial Plant Offerings in Hellenistic Times: An Archaeobotanical Case Study from Messene, Peloponnese, Greece. Vegetation History and Archaeobotany 14: 329-40. [CrossRef]

Moody, Jennifer. 2005. Unravelling the Threads: Climate Changes in the Late Bronze III Aegean. In Ariadne's Threads: Connections between Crete and the Greek Mainland in Late Minoan III (LM IIIA2 to LM IIIC), Proceedings of the International Workshop, Athens, Scuola Archeologica Italiana, 5-6 April 2003. Edited by Anna Lucia D’Agata and Jennifer Moody. Athens: Scuola Archeologica Italiana di Atene, pp. 443-70.

Moody, Jennifer. 2014. Prehistoric and Historic Climate and Weather (East) Crete. In A Cretan Landscape through Time: Priniatikos Pyrgos and Environs. Edited by Barry Molloy and Chloë Duckworth. BAR International Series 2634; Oxford: Archaeopress, pp. 23-30.

Neef, Reinder, Rene Cappers, and Renee Bekker. 2012. Digital Atlas of Economic Plant in Archaeology. Groningen Archaeological Series 17; Groningen: Barkhuis.

Palmer, Carole, and Marijke Van der Veen. 2002. Archaeobotany and the Social Context of Food. Acta Palaeobotanica 42: 195-202.

Pearsall, Deborah. 2015. Paleoethnobotany: A Handbook of Procedures. Walnut Creek: Left Coast Press.

Peatfield, Alan. 1983. The Topography of Minoan Peak Sanctuaries. The Annual of the British School at Athens 78: 273-79. [CrossRef]

Peatfield, Alan. 1990. Minoan Peak Sanctuaries: History and Society. Opuscula Atheniensia 8: 117-31. 
Peatfield, Alan. 2002. Divinity and Performance on Minoan Peak Sanctuaries. In POTNIA: Deities and Religion in the Aegean Bronze Age, Proceedings of the 8th International Aegean Conference/8e Rencontre Egéenne Internationale, Göteborg, Sweden, 12-15 April 2000. Edited by Robert Laffineur and Robin Hagg. Aegaeum 22. Liege: University of Liege, pp. 51-55.

Peatfield, Alan, and Christine Morris. 2012. Dynamic Spirituality on Minoan Peak Santuaries. In Archaeology of Spiritualities. Edited by Kathryn Rountree, Christine Morris and Alan Peatfield. One World Archaeology. New York: Springer, pp. 227-45. [CrossRef]

Picornell-Gelabert, Llorenç, Manuel Calvo Trias, Jaume Rossell, Gabriel Servera-Vives, Giovanna Bosi, Jordi Nadal Lorenzo, Santiago Riera Mora, and Ethel Allu. 2018. Towards an Archaeology of the Social Meanings of the Environment: Plants and Animals at the Prehistoric Ceremonial and Funerary Staggered Turriform of Son Ferrer (Mallorca, Balearic Islands, Spain). In The Bioarchaeology of Ritual and Religion. Edited by Alexandra Livarda, Richard Madgwick and Santiago Riera Mora. Oxford: Oxbow Books, pp. 148-61.

Platon, Nikolaos, and Kostas Davaras. 1961. Archaiotites kai Mnimeia Kritis. Archaiologikon Deltion 17: $281-91$.

Platon, Nikolaos. 1971. Zakros: The Discovery of a Lost Palace of Ancient Crete. New York: Scribner.

Renfrew, Colin. 2011. Prehistoric Religions in the Aegean. In The Oxford Handbook of the Archaeology of Ritual and Religion. Edited by Timothy Insoll. Oxford: Oxford University Press, pp. 681-95.

Romano, David, and Mary Voyatzis. 2014. Mt. Lykaion Excavation and Survey Project, Part 1: The Upper Sanctuary. Hesperia 83: 569-652. [CrossRef]

Rudolph, Kelli. 2017. Taste and the Ancient Senses. New York: Routeledge.

Sabato, Diego, and Leonor Peña-Chocarro. 2021. Maris Nostri Novus Atlas Seeds and Fruits from the Mediterranean Basin. Ediciones: Doce Galles.

Sakellarakis, Yiannis, and Efi Sakellarakis. 1997. Archanes: Minoan Crete in a New Light. Athens: Ammos Publications, vol. 1.

Sakellarakis, Yiannis, and Efi Sapouna-Sakellarakis. 1981. Drama of Death in a Minoan Temple. National Geographic 159: $205-22$.

Sarpaki, Anaya. 2019. Plants in the Sanctuary: Charred Seeds from Areas C and D at the Sanctuary of Poseidon at Kalaureia, Poros. Opuscula. Annual of the Swedish Institutes at Athens and Rome 12: 271-86. [CrossRef]

Savignoni, Luigi. 1904. Scavi e Scoperte Nella Necropoli di Phaistos. Monurnenti Antichi 14: 501-66.

Smith, R. Angus, Mary Dabney, Georgia Kotzamani, Alexandra Livarda, Georgia Tsartsidou, and James C. Wright. 2014. Plant Use in Mycenaean Mortuary Practice. In PHYSIS: L'Environnement Naturel et La Relation Homme-Milieu Dans Le Monde Egeen Protohistorique; Actes de La 14e Rencontre Egeenne Internationale, Paris, Institut National d'Histoire de L'Art (INHA), France, 11-14 Decembre 2012. Edited by Gilles Touchais, Robert Laffineur and Francoise Rougemont. Aegeum 37. Leuven-Liege: Peeters, pp. 265-70.

Soetens, Steven. 2009. Juktas and Kophinas: Two Ritual Landscapes out of the Ordinary. Hesperia Supplements 42: 261-68.

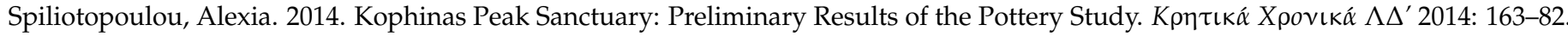

Tsipopoulou, Metaxia. 2009. Goddesses for "Gene"? The Late Minoan IIIC Shrine at Halasmenos, Ierapetra. Hesperia Supplements 42: 121-36.

Tsipopoulou, Metaxia, ed. 2017. Documenting Sociopolitical Chages at the Pre- and Protopalatial Petras: The House Tomb Cemetery. In Petras, Siteia: The Pre-and Protopalatial Cemetery in Context; Acts of a Two-Day Conference Held at the Danish Institute at Athens, 14-15 February 2015. Aarhus: Aarhus University Press, Monographs of the Danish Institute at Athens, vol. 21, pp. 57-97.

Tsipopoulou, Mextaxia, ed. forthcoming. The House Tomb 2, 4 and 10 from Petras. Philadelphia: INSTAP Academic Press, Institute for Aegean Prehistory Monographs.

Valamoti, Soultana. 2011. Flax in Neolithic and Bronze Age Greece: Archaeobotanical Evidence. Vegetation History and Archaeobotany 20: 549-60. [CrossRef]

Verhoeven, Marc. 2011. The Many Dimensions of Ritual. In The Oxford Handbook of the Archaeology of Ritual and Religion. Edited by Timothy Insoll. Oxford: Oxford University Press, pp. 115-32.

Younger, John, and Paul Rehak. 2008. Minoan Culture: Religion, Burial Customs, and Administration. In The Cambridge Companion to the Aegean Bronze Age. Edited by Cynthia Shelmerdine. Cambridge: Cambridge University Press, pp. 165-85. [CrossRef]

Zohary, Daniel, Maria Hopf, and Ehud Weiss. 2012. Domestication of Plants in the Old World: The Origin and Spread of Domesticated Plants in South-West Asia, Europe, and the Mediterranean Basin, 4th ed. Oxford: Oxford University Press. 